\title{
Seismic lines offshore Mount Etna (SOME) open database
}

\author{
Francesco Mazzarini $^{1,}{ }^{*}$, Ilaria Isola $^{1}$, Marina Bisson $^{1}$, Luca Nannipieri ${ }^{1}$, Massimiliano Favalli ${ }^{1}$, \\ Alessandro Fornaciai ${ }^{1}$, Simone Tarquini ${ }^{1}$
}

${ }^{1}$ Istituto Nazionale di Geofisica e Vulcanologia, Pisa, Italy

\author{
Article history \\ Received December 14, 2016; accepted July 10, 2017. \\ Subject classification: \\ Surveys, Measurements and monitoring, Seismological data.
}

\begin{abstract}
The Seismic lines Offshore Mount Etna (SOME) database is presented. It consists of multichannel high-resolution seismic data acquired in 2005 off-shore Mount Etna (eastern Sicily). We describe first the acquisition of seismic lines and then the architecture of the data base. Finally we describe a very basic interpretation of some seismic lines to provide clear example of the potentiality of the seismic data sets in addressing relevant issues such as the occurrence of slope instabilities and the deformation style of the continental margin off shore mount Etna.
\end{abstract}

\section{Introduction}

Flank instability and collapse characterize the dynamics of many volcanoes [e.g., Borgia 1994, Borgia et al. 2000, Milia et al. 2003, Masson et al. 2006, Milia et al. 2012]. Mt. Etna, the largest volcano in Europe, has its structural dynamics principally characterized by volcanic spreading, which results in an overall seaward movement of its eastern sector, accommodated mostly by a large deformation zone in the south-east [Borgia et al. 1992, Lundgren et al. 2004, Catalano et al. 2004] and by the transtensional Pernicana Fault in the north [Groppelli and Tibaldi 1999, Tibaldi and Groppelli 2002].

The large scar of the Valle del Bove and the occurrence of Pleistocene and Holocene debris avalanches and debris-flow deposits characterize the eastern flanks of the volcano (Figure 1); they testify for the collapse of the Mt. Etna due to the eastward spreading of the volcano [Calvari and Groppelli 1996, Calvari et al. 1998, Del Negro and Napoli 2002, Calvari et al. 2004]. The seaward extension of the volcano is controlled by the NNW-SSE trending Malta Escarpment fault system [Monaco et al. 1997], which has been recognised offshore in previous deep reflec- tion seismic surveys [Nicolich et al. 2000]. Recent studies define a complex structural setting of the area offshore Mount Etna (Figure 1) due to the co-occurrence of continental slope dynamics, magmatic and tectonics processes [Doglioni et al. 2001, Froger et al. 2001, Chiocci et al. 2011, Argnani et al. 2013, Carlino et al. 2016, Gross et al. 2014, Gross et al. 2016]. All these processes can increase the tsunamigenic potential of the area being the problem of an assessment of the volcano flank-failure hazard very important [Pareschi et al. 2006, Billi et al. 2008, Argnani et al. 2009, Favalli et al. 2009, Grezio et al. 2012, Barbano et al. 2014, Kawamura et al. 2014].

In order to explore the submarine part of the volcano (Figure 1), during the spring 2005 the Istituto Nazionale di Geofisica e Vulcanologia commissioned the acquisition of multichannel seismic profiles in the area to image shallow crustal levels at very high vertical and horizontal seismic resolution [Pareschi et al. 2006].

In the following, we provide a description of the seismic survey, present the structure of the data base "Seismic multichannel data Offshore Mount Etna" (SOME) and discuss some interpreted seismic profiles of the data base.

The SOME database is open access to provide the maximum diffusion and sharing of multichannel seismic data and to offer the possibility to analyse these data to the scientific community.

\section{Material and methods}

In May $2005, \sim 480 \mathrm{~km}$ of high resolution $2 \mathrm{D}$ multichannel seismic profiles have been collected in the Ionian Sea, offshore Mt. Etna. The "Istituto Nazionale di Geofisica e Vulcanologia” contracted with FUGRO OCEAN- SISMICA S.p.A. to conduct the survey. The 


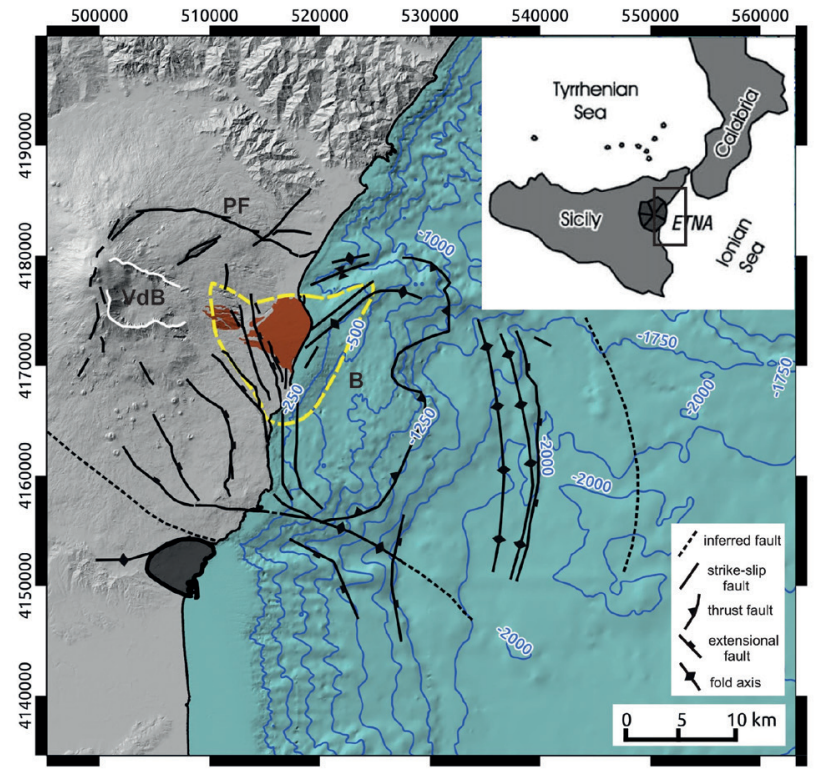

Figure 1. Structural sketch map of the Etna [modified after Pareschi et al. 2006]. The hillshade map is a merge between the TINITALY DEM [Tarquini et al. 2007] and the bathymetry from IIM [Tarquini et al. 2008]. ML: Holocene Milo debris avalanche deposits (>8400 yr B.P.); CH: Chiancone Conglomerate (>7600 $\pm 130 \mathrm{yr}$ B.P.), [Calvari et al. 1998, Calvari and Groppelli 1996]. Solid black lines are traces of the main faults in the area; PF: Pernicana Fault; VdB: Valle del Bove; B: off-shore bulging area. The dashed yellow line represents the inland and offshore extension of coastal volcaniclastic deposits as imaged by a recent magnetic survey [Del Negro and Napoli 2002]. Structural elements redrawn from Gross et al. [2016] and Argnani et al. [2013]. Inset shows the location of the studied area (black box).

investigated area consists of a sea sector from Catania to Taormina (latitude $37^{\circ} 25^{\prime} 00^{\prime \prime} \mathrm{N}-37^{\circ} 50^{\prime} 00^{\prime \prime} \mathrm{N}$ and from the coast to longitude $15^{\circ} 30^{\prime} 00^{\prime \prime} \mathrm{E}$ ) extending from depths of $100-2000 \mathrm{~m}$. The whole data set is shown in Figure 2.

The seismic streamer utilized was a Litton Industries quick coupler with 96 traces and a group interval of $12.5 \mathrm{~m}$, for a total active streamer length of $1200 \mathrm{~m}$. The streamer was connected to a TTS-II digital data recording system with a sampling interval of $1 \mathrm{~ms}$ and a record length of $3 \mathrm{~s}$. The near offset trace was recorded $72 \mathrm{~m}$ from the vessel common reference point, with an offset of $51.2 \mathrm{~m}$ between the source and this trace. The seismic source was an airgun array of total size of $120 \mathrm{inch}^{3}$ operated at a pressure of 2000 psi. The shooting interval was 12.5 ms with time accuracy of $\pm 0.05 \mathrm{~ms}$; ; the source and streamer were towed approximately $2.5 \mathrm{~m}$ below sea level. The raw seismic data were recorded in SEG-D format on type 3490 tape cartridges. A total of 40 seismic lines have been processed.

Processing was carried out using Fugro Seismic Imaging Uniseis software; the data shot had 96 channels, $1 \mathrm{~ms}$ sample interval, and $3000 \mathrm{~ms}$ record length.
The major steps of the processing sequence consist of: trace editing, gain recovery, sorting in the cmp domain, velocity analysis, pre-stack time migration, NMO correction and $\mathrm{cmp}$ stacking. Muting in the CDP domain was done. This was a top mute to remove NMO stretch. The mute was applied with 2 traces remaining at the seabed for shallow areas (WB $<1000 \mathrm{~ms}$ ) or 4 traces remaining for deeper areas. Full-fold data (no traces muted) was used after WB $+800 \mathrm{~ms}$; the migration algorithm to correctly migrate the data uses the resulting velocity field.

A first pass velocity analysis was performed at $1 \mathrm{~km}$ intervals along each line. A second pass analysis at $500 \mathrm{~m}$ intervals was performed after migration to account for changes in move out resulting from the migration process.

The data were migrated pre-stack with a Kirchhoff summation algorithm; the velocity field derived at $1 \mathrm{~km}$ intervals was used with no scaling. The $\mathrm{P}$ wave interval velocity along profiles was estimated by applying the Dix equation, with the RMS stacking velocity and ranges from 1700 to $2200 \mathrm{~ms}^{-1}$ as input parameters according to velocity range used in Leslie et al. [2002]. A post-stack time variant filter was applied near the end of the processing sequence (Table 1). The dominant frequency of the reflected signal throughout sections was about $90 \mathrm{~Hz}$. In this acoustic framework, the vertical resolution limit is $5-7 \mathrm{~m}$, while the horizontal limit is about $200 \mathrm{~m}$ at $2.0 \mathrm{~s}$ two way travel time (TWT) [Yilmaz 1987].

\section{The SOME data base}

The Seismic multichannel data Offshore Mount Etna (SOME) database has a very simple structure and consists of 39 records representing the seismic lines (Figure 2) and a folder (NAV-DATA) common for all the seismic lines with the NCDP Total Position data, in UKOOA format. Each record consists of a folder containing:

i) the text file with the name of the line, seismic data acquisition, the applied filters (lower and upper frequencies cut offs), record length, number of traces and CDP, and the data format;

ii) the seismic line in SEG_Y format (https:// pubs.usgs.gov/of/2001/of01-326/HTML/ FILEFORM.HTM);

iii) a quick look in raster format (.BMP) of the line.

The SOME data can be browsed at http:/ / some. pi.ingvit (by clicking on the code of the seismic lines). 


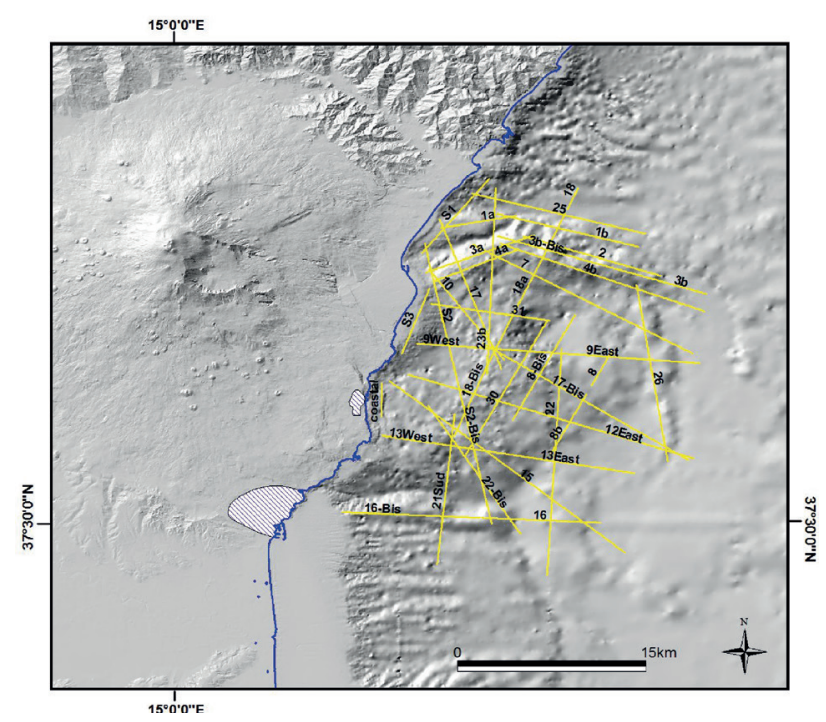

Figure 2. Seismic grid offshore of Mount Etna. The seismic lines (yellow/with solid lines) are those present in the SOME data base.

Clicking on the code of each seismic line a quicklook of the line is displayed. In order to download the desired lines users should register and can download the data from the website. This is a standard web service with the custom CGI (Common Gateway Interface) to manage the users requests and data access (Figure 3). The custom CGI processes the information provided by users during registration and after a preliminary check sends them the access account. After that, the custom CGI manages the users access and allows them to download data. The data are organized in files and are stored in a linux server file system.

\begin{tabular}{lcc}
\hline Time $(\mathbf{m s})$ & $\begin{array}{c}\text { Low-cut Slope } \\
(\mathbf{H z} ; \text { dB } / \text { oct. })\end{array}$ & $\begin{array}{c}\text { High-cut Slope } \\
(\text { Hz; dB } / \text { oct. })\end{array}$ \\
\hline WB 0 & $30-18$ & $375-72$ \\
WB +800 & $8-18$ & $375-72$ \\
WB +1600 & $8-18$ & $160-72$ \\
WB +3000 & $8-18$ & $60-72$ \\
\hline
\end{tabular}

Table 1. Parameters of pre-stack filters applied to the processing sequence.

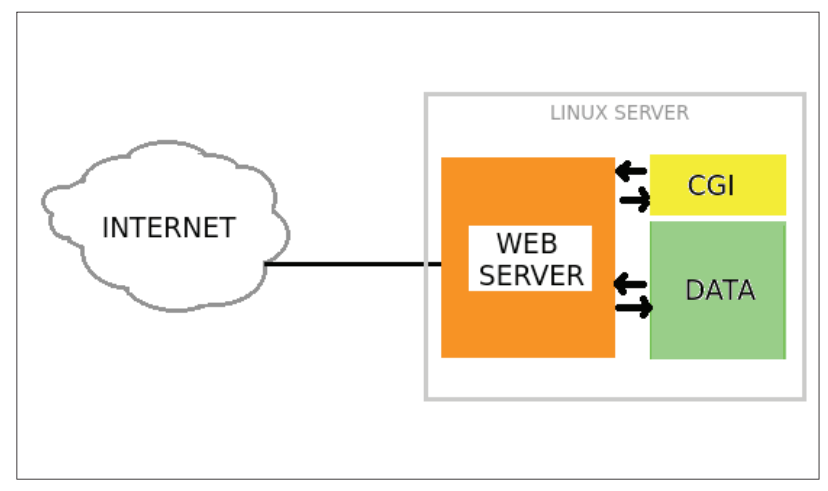

Figure 3. User interface scheme of the website http//:some. pi.ingvit.

\section{Discussion}

The interpretation of the seismic reflection database shows structural, morphological and erosional features. Some good examples of the structures observed along the continental margin off-shore Mt. Etna imaged by the (SOME) seismic data are described in the following.

Reflection terminations (e.g., onlap, downlap, erosional truncation) were used to identify major sequence boundaries/unconformities on seismic sections. The seismic facies used (Figure 4a) include high-amplitude reflections, continuity, frequency variation, and lap geometries [e.g., Alsulami et al. 2015 and references therein].

\subsection{Malta Escarpment structure}

On the basis of seismic and bathymetric data the late Pleistocene evolution of the continental margin in eastern Sicily has been linked to both tectonic [Argnani et al. 2013] and magmatic [Chiocci et al. 2011] processes. The Malta Escarpment is the dominant morphological feature offshore eastern Sicily, linking the deep Ionian basin to the east with the Hyblean carbonate platform to the west [e.g. Argnani and Bonazzi 2005]. The segment of the Malta Escarpment off-shore Mount Etna is characterized by the presence of NNWSSE, east-dipping recent extensional faults and related sedimentary basins [Argnani and Bonazzi 2005].

Seismic line 15 runs NW-SE and is orthogonal to the coast extending offshore Acireale until depth of $1900 \mathrm{~m}$ (Figures 1, 2 and 4b).

From west to the east, the seismic line images: continental slope, fault escarpment and basin features (Figure $4 \mathrm{~b}$ ). In the upslope portion of the line (continental slope in Figure 4b) high amplitude reflectors are faulted; low to medium amplitude, high frequency reflectors fill the fault-bounded depressions (Figure 5a). High amplitude wavy to hummocky clinoforms reflections with intervening disturbed and chaotic reflections are interpreted as resulting from a westward dipping fault (Figures $4 \mathrm{~b}$ and $5 \mathrm{a}$ ) with large offsets (up to $400 \mathrm{~ms}$, TWT).

Well-stratified deposits are in the basin in the eastward line termination (Figures $4 \mathrm{~b}$ and $5 \mathrm{~b}$ ). Deposits generally show well organized, mainly planar/parallel reflections with medium amplitude. Unconformities are imaged in the basin delimited by the fault escarpment where a syn-sedimentary wedge suggests a period of fault-controlled deposition within the basin (Figure $5 \mathrm{~b}$ ). Along the line cuspate erosional features in thin slope deposits are often imaged (Figure 4b); 

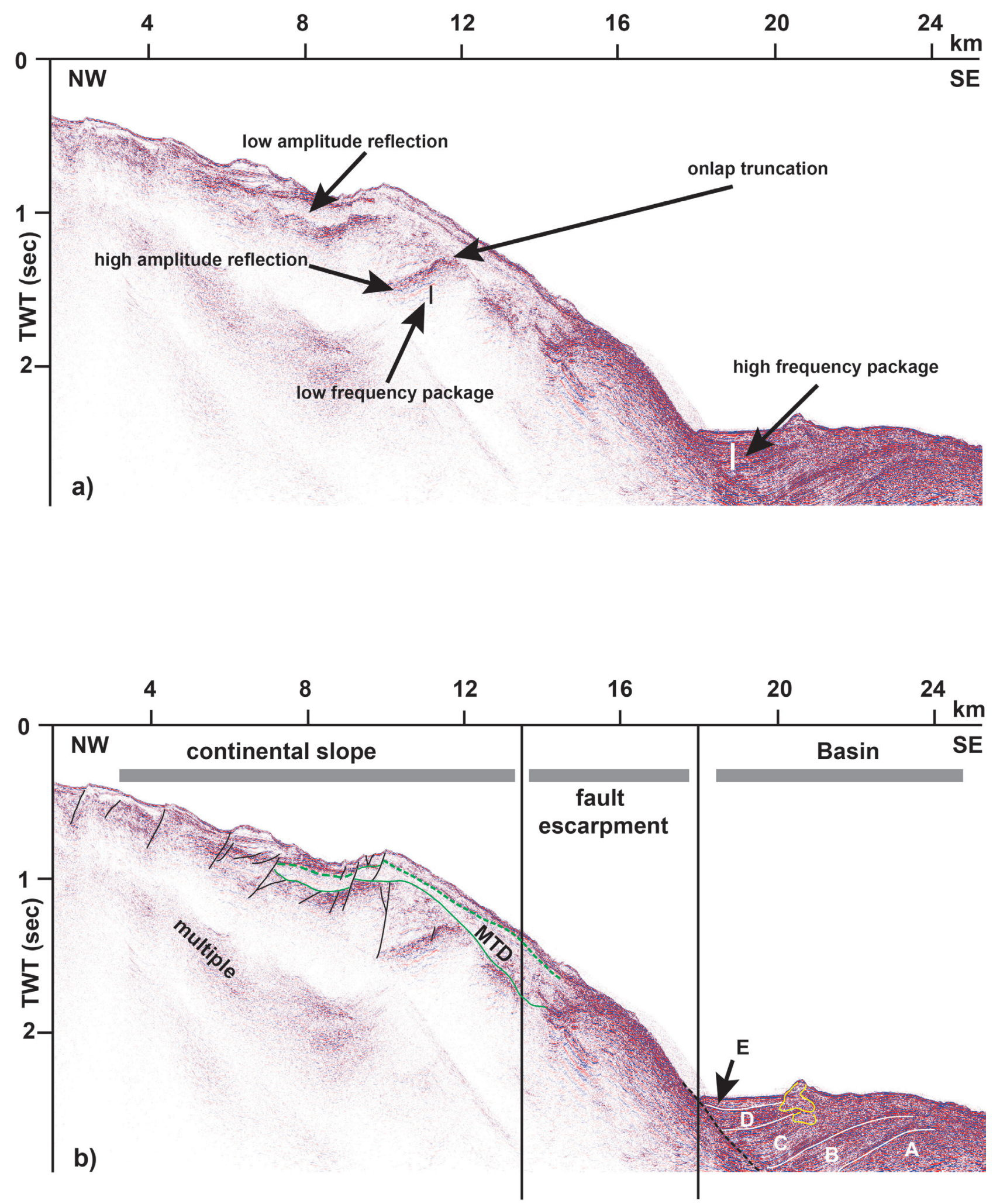

Figure 4. a) The main seismic features used to interpret the seismic lines are indicated in the seismic line 15 of the SOME data base (see Figure 2 for line location). b) Interpreted seismic section with the outline of the main features, from the west: the continental slope, the fault escarpment (thick dashed black line) and the basin. Black lines are faults, white lines are reflectors and green lines are bottom (thick) and top (dashed) boundaries of the MTD. MTD: Mass Transport Deposits. A, B ,C, D, E are the seismic unit described in the main text. Yellow lines defines exotic blocks in the basin.

they have variable amplitude reflectors with complex mounds, blocks and chaotic disrupted reflections. Mass-Transport Deposits (MTD) are imaged along the slope covered by thin eroded sedimentary cover and as blocks interlayered within deposits (Figures $4 \mathrm{~b}$ and 5 ).

A prominent fault escarpment (Figure $4 \mathrm{~b}$ ) sep- 

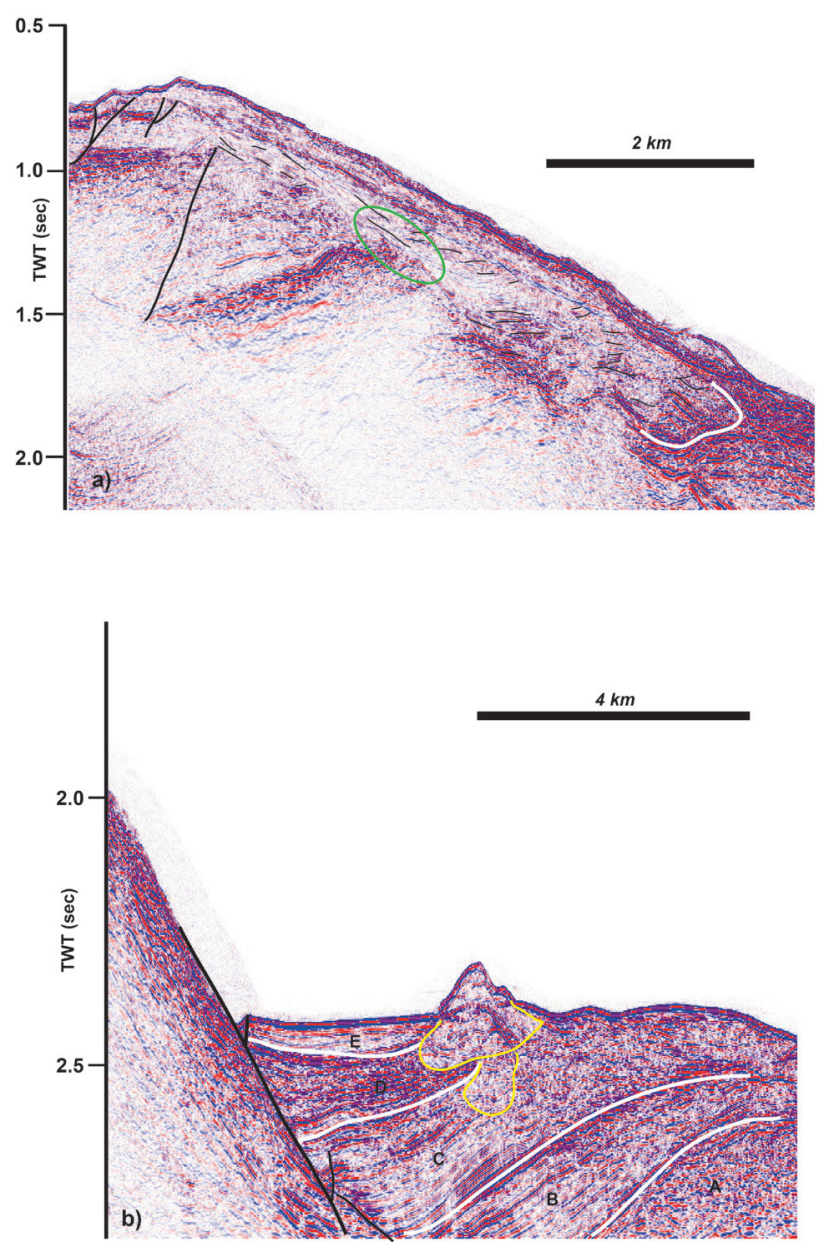

Figure 5. a) Close up of the slope area along the line 15. The high amplitude faulted (fault: black line) reflectors have toplap truncation with the MTD unit (green ellipse), reflectors within the MTD are displayed as thin black lines. White lines highlight the MTD toe. b) Close up of the basin area along the line 15. The seismic units have been coded from A (the lowest) to $\mathrm{E}$ (the highest). Thick white lines mark the units' boundaries. Black lines are main fault (thick lines) and minor faults (thin lines). The yellow lines mark the block deposited inside the basin.

arates the slope from the basin; it consists of high frequency, high amplitude reflectors with contorted reflectors packages interlayered with high amplitude eastward dipping continuous reflectors (Figures $4 \mathrm{~b}$ and 5b). Argnani et al. [2013] interpreted this fault as belonging to the Malta Escarpment Fault system.

The complex evolution of the continental margin is recorded in the basin at the eastward termination of the NW-SE line (Figure $4 \mathrm{~b}$ ). East dipping main fault escarpment bounds a hanging wall basin where five seismic units can be defined (Figure $5 b$ ).

Unit A is the deepest feature consisting of high frequency, medium amplitude contorted reflectors and it may represent a westward tilted block in the hanging wall of the main fault. The tilting of the block is clearly documented by a decreasing deep of younger basin reflectors (Figure $5 b$ ).
High to medium amplitude high frequency continuous reflectors characterize Unit B, they have top lap truncation with reflectors of Unit $A$ and show deformation approaching the main fault (Figure $5 \mathrm{~b}$ ).

Unit $C$ shows continuous alternating high to low amplitude westward dipping reflectors that, approaching the main fault, show antithetic faulting and a synform geometry suggesting dragging and syn-faulting deposition (Figure $5 \mathrm{~b}$ ). At the top of unit $\mathrm{C}$, the geometry of the reflectors is disrupted by blocks with chaotic, disrupted reflectors; these blocks may be interpreted as MTD that fell into the basin during the late stages of deposition of unit $\mathrm{C}$.

In unit $\mathrm{D}$, continuous high amplitude medium frequency reflectors onlap the top of the unit $\mathrm{C}$ and are disrupted eastward by exotic blocks with contorted and chaotic reflectors (Figure 5b). The clear drag of reflectors close to the main fault suggests again syn-faulting deposition with contribution of exotic blocks (MTD).

The uppermost and younger unit (E) consists of continuous low amplitude high frequency reflectors abutting eastward to an exotic block (see units $\mathrm{C}$ and D); towards the main fault the reflectors are faulted (Figure 5b).

\subsection{Mass-Transport Deposits}

Mass-Transport Deposits (MTDs) reflect one of the key processes shaping continental margins, transferring large masses of sediment from proximal to distal slope domains [Hampton et al. 1996, Masson et al. 2006, Li et al. 2015].

Pareschi et al. [2006] and Argnani et al. [2013] reported in the continental margin off Mount Etna submarine MTDs, including both debris avalanche and slumps [sensu Moore et al. 1989]. The occurrence of volcaniclastic debris in sampled MTD suggests that both volcanic and non-volcanic processes may control slope failures in this area [Gross et al. 2014]. The volcano-tectonic control in the evolution of the area has been confirmed by Gross et al. [2016] from the interpretation of high resolution seismic profiles.

These deposits are shown by line 15 (Figure $4 \mathrm{~b}$ ) of the SOME database. They are characterized by high frequency, low amplitude disrupted reflections. The base of the MTD is in onlap truncation on faulted low frequency high amplitude reflectors (Figure $4 \mathrm{~b}$ and 5a). At the toe of the MTD (Figures $4 \mathrm{~b}$ and 5a) reflectors packages show different dip angles and internal deformation. The MTDs along the seismic 

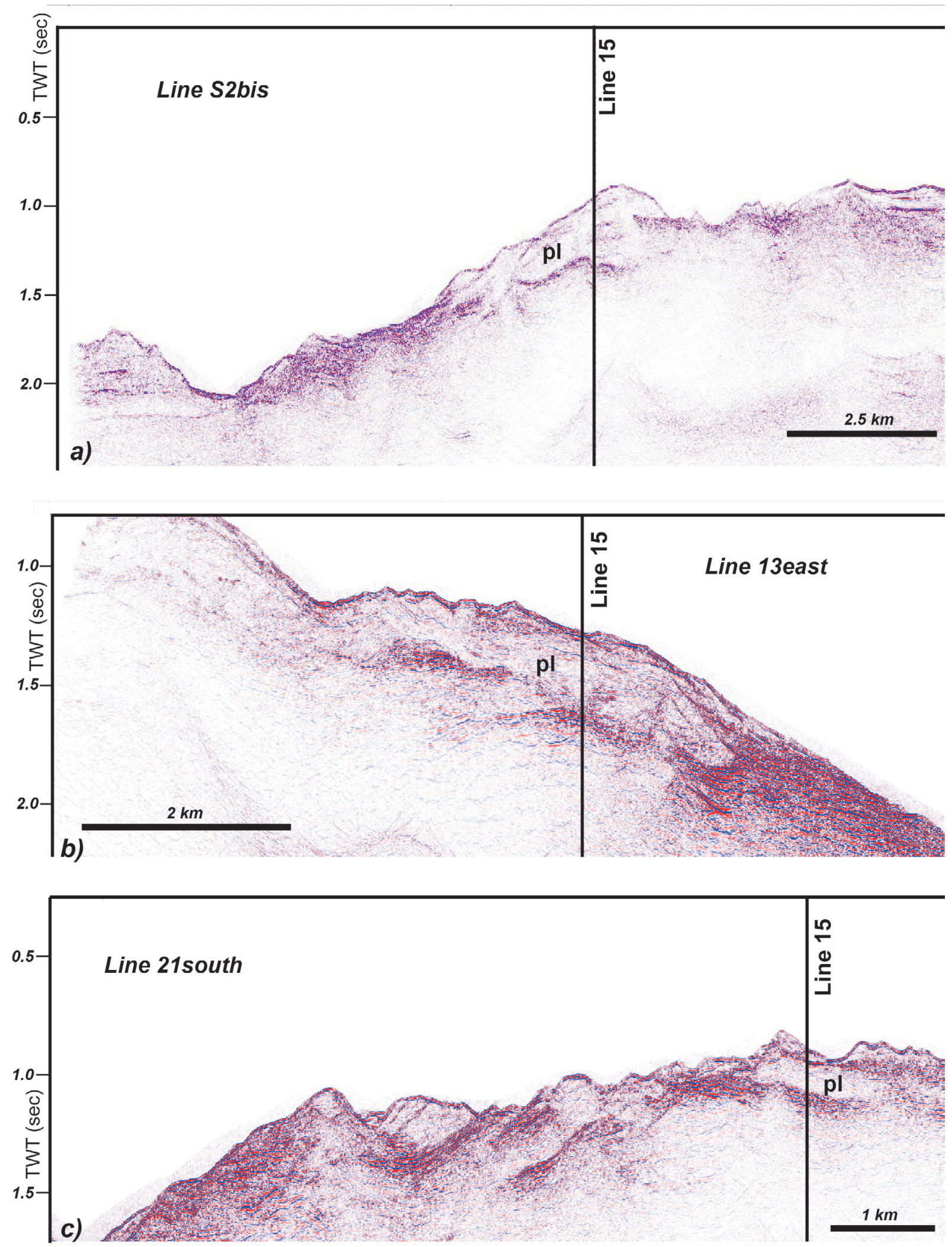

Figure 6. MTD limits along some of the sections that intercept it (pl: paleolandslide). Solid vertical line is the intercept with the line 15 (Figure 4). a) Line S2bis; b) Line 13east; c) Line 21sud.

line is covered by deposits and are here interpreted as a record of former slope instabilities. By cross-correlation of the data sets (Figure 6) we mapped the MTD (Figure 7).

The MTD cover an area of about $13 \mathrm{~km}^{2}$, its thickness in TWT varies in the range 0.230-0.342 s with an average of $0.277 \mathrm{~s}$. The sea bottom along the trace of the MTD varies between 1100 and $1300 \mathrm{~m}$ b.s.l, taking into account that the seismic velocity of sediments may vary in function of their porosity, gas 


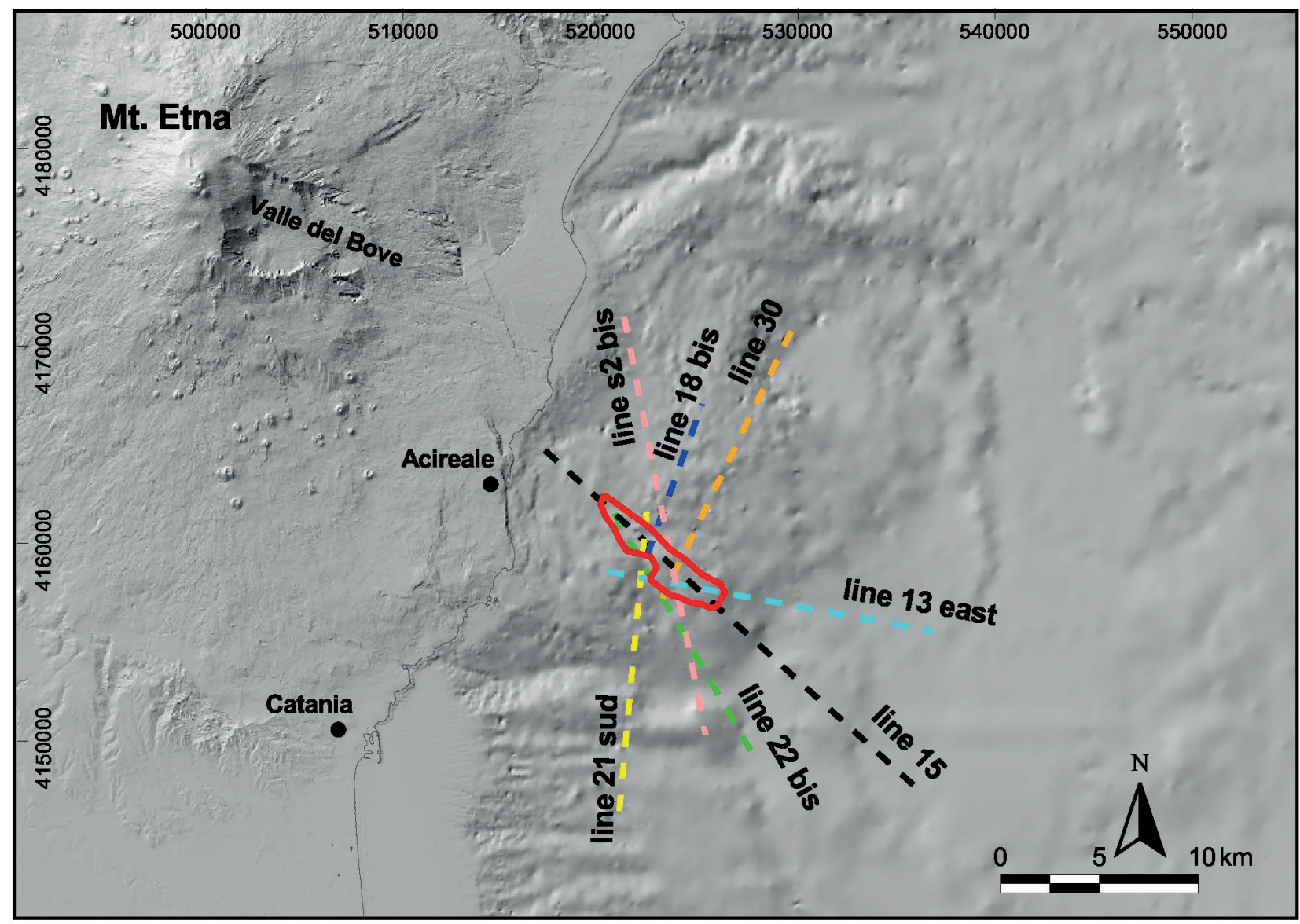

Figure 7. MTD extent (red line) and traces of the used seismic lines used to define it.

content and water depth [Nafe and Drake 1957, Yuan et al. 1994, Carcione and Tinivella 2000] we assume a seismic velocity varying in the $1700-2500 \mathrm{~m} / \mathrm{s}$ range. As a first rough estimation, the volume of the MTD (Figure 7) is in the 2.5-5.6 $\mathrm{km}^{3}$. MTDs with size in this estimated range have been postulated to contribute, together with the sea floor coseismic slip, to the tsunami in the aftermath of the 1908 Messina earthquake [Favalli et al. 2009]. It is important to note that the MTD volume estimation here presented has been computed assuming that the whole volume has been deposited during a single episode.

Pareschi et al. [2006] and Argnani et al [2013] postulated a long lasting history of MTDs off-shore Mount Etna. Chiocci et al. [2011], using high resolution morphologic and geophysical data, documented a large bulge offsetting of the continental margin characterized by semi-circular structures interpreted as record of large scale gravitational instabilities. Moreover, Gross et al. [2014], using seismic profiles and sediment cores defined the occurrence of repeated MTD events again supporting a long history of landslides in the working area. As discussed above, the syn-faulting, hanging wall basin imaged in the line 15 (Figures $4 \mathrm{~b}$ and $5 \mathrm{~b}$ ) clearly shows ep- isodes of MTD that occurred since the deposition of the unit $\mathrm{C}$, thus supporting a long lasting history of mass transport deposits due to slope instabilities. A MTD with a size of $2.5-5.6 \mathrm{~km}^{3}$ is already a very large deposit offshore Mt Etna, it lays in unconformity above the faulted continental slope (Figure $4 \mathrm{~b}$ ) and its source could be somewhere upslope. It is not possible to ascribe the blocks in the basin downslope the MTD as belonging to this large landslide (MTD) only by the interpretation of a single seismic line.

Furthermore, the high erosion rates characterizing this area [e.g. Argnani et al. 2013, Chiocci et al. 2011] could easily remove any record of the propagation of this large landslide into the basins.

\section{Conclusions}

The SOME database consists of multichannel high-resolution seismic lines acquired in 2005 offshore Mount Etna. This data set may provide useful clues about the understanding of tectonic, magmatic and gravitational processes acting on the continental margin of the eastern Sicily. The SOME database is open in order to foster the data sharing within the scientific community and to favour scientific collaboration. 


\section{References}

Alsulami, S., Paton, D.A., Cornwell, D.G., 2015. Tectonic variation and structural evolution of the West Greenland continental margin. AAPG Bulletin, 99/9, 1689- 1711.

Argnani, A., Bonazzi, 2005. Malta Escarpment fault zone offshore eastern Sicily: Pliocene-Quaternary tectonic evolution based on new multichannel seismic data. Tectonics, 24, TC4009, doi:10.1029/2004TC001656.

Argnani, A., F. L. Chiocci, S. Tinti, A. Bosman, M. V. Lodi, G. Pagnoni, and F. Zaniboni (2009), Comment on "On the cause of the 1908 Messina tsunami, southern Italy” by Andrea Billi et al., Geophys. Res. Lett., 36, L13307, doi:10.1029/ 2009GL037332.

Argnani, A., Mazzarini, F., Bonazzi, C., Bisson, M., Isola, I., 2013. The deformation offshore of Mount Etna as imaged by multichannel seismic reflection profiles. Journal of Volcanology and Geothermal Research, 251, 50-64.

Barbano, M.S., Castelli, V., Pantosti, D., Pirrotta, C., 2014. Integration of historical, archaeoseismic and paleoseismological data for the reconstruction of the early seismic history in Messina Strait (south Italy): the 1 st and 4 th centuries AD earthquakes. Annals of Geophysics, 57, 1, 2014, S0192; doi:10.4401/ ag-6369 S0192.

Billi, A., Funiciello, R., Minelli, L., Faccenna, C., Neri, G., Orecchio, B., Presti, D., 2009. On the cause of the 1908 Messina tsunami, southern Italy. Geophysical Research Letters, 35, L06301, doi:10.1029/2008GL033251, 2008.

Borgia, A., 1994. Dynamic basis of volcanic spreading. J. Geophys. Res. 99:17791-17804

Borgia, A., Ferrari, L., Pasquare`, G., 1992. Importance of gravitational spreading in the tectonic and volcanic evolution of Mount Etna. Nature, 357, 231-235.

Borgia, A., Delaney, P.T., Denlinger, R.P., 2000. Spreading Volcanoes. Annu. Rev. Earth Planet. Sci., 2000, 28, 539-70.

Calvari, S., Groppelli, G., 1996. Relevance of the Chiancone volcaniclastic deposits in the recent history of Etna volcano (Italy). J. Volcanol. Geotherm. Res., 72, 239-258.

Calvari, S., Tanner, L.H., Groppelli, G., 1998. Debris-avalanche de-posits of the Milo Lahar sequence and the opening of the Valle del Bove on Etna volcano (Italy). J. Volcanol. Geotherm. Res., 87, 193-209.

Calvari, S., Tanner, L.H., Groppelli, G., Norini, G. 2004. Valle del Bove, eastern flank of Etna volcano: A comprehensive model for the opening of the de- pression and implications for the future hazards. In: Mt. Etna: Volcano Laboratory, Geophys. Monogr. Ser., vol. 143, edited by A. Bonaccorso, pp. 65-75, AGU, Washington, D. C.

Carcione, J.M., Tinivella U., 2000. Bottom-simulating reflectors: Seismic velocities and AVO effects. Geophysics, 65,1, 54-67.

Carlino, M.F., Zgur, F., Bruno, P-P.G., Coltelli, M., Sormani, L., Cavallaro, D., Ibáñez, J.M., Patanè, D., 2016. Acquisition and preliminary analysis of multi-channel seismic reflection data, acquired during the oceanographic cruises of the TOMO-ETNA experiment. ANNALS OF GEOPHYSICS, 59, 4, 2016, S0430; doi:10.4401/ag-7083.

Catalano, S., Torrisi, S., Ferlito, C., 2004. The relationship between Late Quaternary deformation and volcanism of Mt. Etna (eastern Sicily): New evidence from the sedimentary substratum in the Catania region. J. Volcanol. Geotherm. Res., 132, 311-334.

Chiocci, F.L., Coltelli, M., Bosman, A., Cavallaro, D., 2011. Continental margin large-scale instability controlling the flank sliding of Etna volcano. Earth and Planetary Science Letters, 305, 1-2, 57-64.

Del Negro, C., Napoli, R., 2002. Ground and marine magnetic surveys of the lower eastern flank of Etna volcano (Italy). J. Volcanol. Geotherm. Res., 114, 357-372.

Doglioni, C., Innocenti, F., Mariotti, G., 2001. Why Mt Etna? Terra Nova, 13, 25-31.

Favalli, M., Boschi, E., Mazzarini, F., Pareschi, M.T., 2009. Seismic and landslide source of the 1908 Straits of Messina tsunami (Sicily, Italy). Geophysical Research Letters, 36, L16304, doi:10.1029/2009GL039135.

Froger, J.L., Merle, O., Briole, P., 2001. Active spreading and regional extension at Mount Etna imaged by SAR interferometry. Earth Planet. Sci. Lett., 187, 245-258

Grezio, A., Sandri, L., Marzocchi, W., Argnani, A., Gasparini, P., Selva, J., 2012. Probabilistic tsunami hazard assessment for Messina Strait Area (Sicily, Italy). Natural Hazards, 64, 329-358.

Groppelli, G., Tibaldi, A., 1999. Control of rock rheology on deformation style and slip-rate along the active Pernicana Fault, Mt. Etna, Italy. Tectonophysics, 305, 521-537.

Gross, F., Krastel, S., Chiocci, F.L., Ridente, D., Bialas, J., Schwab, J., Beier, J., Cukur, D., Winkelmann, D., 2014. Evidence for submarine landslides offshore Mt. Etna, Italy. In: Krastel, S. (Ed.) Submarine Mass 
Movements and Their Consequences, Bd. 37, , 307316, http: / / dx.doi.org/10.1007/978-3-319-009728_27.

Gross, F., Krastel, S., Geersen, J., Behrmann, J.H., Ridente, D., Chiocci, F.L., Bialas, J., Papenberg, C., Cukur, D., Urlaub, M., Micallef, A., 2016. The limits of seaward spreading and slope instability at the continental margin offshore Mt Etna, imaged by high-resolution 2D seismic data. Tectonophysics, 667, 63-76.

Hampton, M.A., Lee, H.J., Locat, J., 1996. Submarine landslides. Rev. Geophys. 34 (1), 33-59.

Kawamura, K., Laberg, J.S., Kanamatsu, T., 2014. Potential tsunamigenic submarine landslides in active margins. Marine Geology, 356, 44-49.

Leslie, S.C., Moore, G.F., Morgan, J.K., Hills, D.J., 2002. Seismic stratigraphy of the frontal Hawaiian moat: Implications for sedimentary processes at the leading edge of an oceanic hotspot trace. Marine Geology, 184, 143 - 162.

Li, W., Alves, T.M., Wu, S., Völker, D., Zhao, F., Mi, L., Kopf, A., 2015. Recurrent slope failure and submarine channel incision as key factors controlling reservoir potential in the South China Sea (Qiongdongnan Basin, South Hainan Island). Mar. Pet. Geol. 64, 17-30.

Lundgren, P., Casu, F., Manzo, M., Pepe, A., Berardino, P., Sansosti, E., Lanari, R., 2004. Gravity and magma induced spreading of Mount Etna volcano revealed by satellite radar interferometry. Geophys. Res. Lett., 31, L04602, doi:10.1029/2003GL018736.

Masson, D.G., Harbitz, C.B., Wynn, R.B., Pedersen, G., LØvholt, F., 2006. Submarine landslides: processes, triggers and hazard prediction. Phil. Trans. R. Soc. A, 364, 2009-2039.

Milia A., Torrente M.M. \& Zuppetta A. (2003) Offshore debris avalanches at Somma-Vesuvius volcano (Italy): implications for hazard evaluation. Journal of the Geological Society, 160, 309-317.

Milia A., Torrente M.M. \& Bellucci F. (2012) A possible link between faulting, cryptodomes and lateral collapses at Vesuvius volcano (Italy). Global and Planetary Change, 90-91, 121-134, doi 10.1016/j. gloplacha.2011.09.011.

Monaco, C., Tapponier, P., Tortorici, L., Gillot, P.Y., 1997. Late quaternary slip-rates on the Acireale-Piedimonte normal fault and tectonic origin of Mt. Etna (Sicily). Earth Planet. Sci. Lett., 147, 125- 139.

Moore, J. G., Clague, D.A., Holcomb, R.T.,. Lipman, P.W, Normak, W.R., Torresan, M.E., 1989. Prodigious submarine landslides on the Hawaiian ridge.
J. Geophys. Res., 94, 17,465-17,484.

Nafe, J.E., Drake, C.L., 1957. Variation with depth in shallow and deep water marine sediments of porosity, density and the velocities of compressional and shear waves. Geophysics, 22,3, 533-552.

Nicolich, R., Laigle, M., Hirn, A., Cernobori, L., Gallart, J., 2000. Crustal structure of the Ionian margin of Sicily: Etna volcano in the frame of regional evolution. Tectonophysics, 329, 121-139.

Pareschi, M.T., Boschi, E., Mazzarini, F., Favalli, M., 2006. Large submarine landslides offshore Mt. Etna. Geophysical Research Letters, 33, L13302, doi:10.1029/2006GL026064.

Ridente, D., Martorelli, E., Bosman, A., Chiocci, F.L., 2014. High-resolution morpho-bathymetric imaging of the Messina Strait (Southern Italy). New insights on the 1908 earthquake and tsunami. Geomorphology, 208, 149-159.

Tarquini, S., Isola, I., Favalli, M., Mazzarini, F., Bisson, M., Pareschi, M. T., Boschi, E., 2007. TINITALY / 01: a new Triangular Irregular Network of Italy. Annals of Geophysics, 50, 407-425.

Tarquini, S., Bisson, M., Isola, I., Nannipieri. L., 2008. Immagini di modelli digitali a medio/alta risoluzione navigabili via web: un esempio di condivisione di banche dati geografiche di grandi dimensioni tramite Google Earth. Rapporti Tecnici INGV, 73, 1-24, http:/ / istituto.ingv.it/1-ingv/produzione-scientifica/rapporti-tecnici-ingv/rapporti-tecnici-2008.

Tibaldi, A., Groppelli, G., 2002. Volcano-tectonic activity along structures of the unstable NE flank of Mt. Etna (Italy) and their possible origin. Journal of Volcanology and Geothermal Research, 115, 277-302.

Yilmaz, O., 1987. Seismic data processing. Invest. Geophys., vol. 2, Soc. of Explor. Geophys., 562 pp., Tulsa, Okla.

Yuan, T., Spence, G.D., Hyndman, R.D., 1994. Seismicv elocitiesa nd inferred porositiesin the accretionaryw edge sediments at the Cascadia margin. Journal of geophysical Research, 99, B3, 413-442.

\footnotetext{
${ }^{*}$ Corresponding author: Francesco Mazzarini, Istituto Nazionale di Geofisica e Vulcanologia, Sezione di Pisa, Pisa, Italy; email: francesco.mazzarini@ingv.it
}

2017 by Istituto Nazionale di Geofisica e Vulcanologia. All rights reserved 